\title{
Impacts of Land Use and Land Use Change In River Basin to Water Quality of Cirarab River, Indonesia
}

\author{
Kus Indriyani ${ }^{1}$, Hayati Sari Hasibuan ${ }^{* 2}$, Misri Gozan ${ }^{3}$ \\ \{kusindriyani2110@gmail.com ${ }^{1}$, hayati.hasibuan@ui.ac.id*2, mrgozan@gmail.com\} \\ School of Environmental Science, Universitas Indonesia, Jakarta 10430, Indonesia ${ }^{1,2}$, Department of \\ Chemical Engineering, Universitas Indonesia, Depok 16242, West Java, Indonesia ${ }^{3}$
}

\begin{abstract}
Land use and land cover (LULC) changes are two main factors contribute to the decreasing water quality. This research aims to assess the impacts of LULC changes on the river basin towards water quality of Cirarab River. This research applied GIS analysis with LULC data changes from 2013 to 2018. The potential pollution load originating from residential on the river basin was calculated and compared to the maximum pollutant load. Water samples were collected five times a day in three locations. The result showed residential and industrial areas increased respectively of 110.08ha and 388.37ha; while shrub/vacant land decreased by 407.15ha. Potential pollution load amounted to $2615.78 \mathrm{kgBOD} /$ day and $3713.87 \mathrm{kgCOD} / \mathrm{day}$. This study found almost all monitoring points of COD and BOD parameters exceeded the required quality standard. Water samples collected from river basin with shrubs/vacant land has relatively better water quality compared to those collected from residential and industrial areas.
\end{abstract}

Keywords: land-use change, land cover, water quality, pollution load, river.

\section{Introduction}

Water is a basic human need that is at the core of sustainable development and is critical for socio-economic development, healthy ecosystems, and for human survival itself [1]. The availability of clean water is heavily influenced by pollution [2], and most of the water quality problems are caused by wastewater from human activities to meet their livelihoods such as industrial, household, and agricultural activities [3] that cause changes in land use [4]. Further, river water quality is also influenced by land use in the river basin because human activities can be described by land used on river basin [5]. As the city grows, the riparian zone is forced by the increasing pressure to convert urban riparian zone, where riparian vegetation decreases while built and agricultural land increase [6]. The Population increase has an impact on landuse change around the river area, which will expand the built land and areas that are unable to absorb water.

Further, this will cause water flowing to the river to become faster and with higher volume. Land use will also affect river water quality. Land use and land-use changes are the main drivers of the decline in river water quality [7] [8] [9]. The declining river water will decrease the river's carrying capacity to receive waste from human activities. Understanding the relationship between land use and water quality is useful to identify what are the primary threats towards water quality, and principal for adequate water quality management [7]. 
Many recent studies have provided an understanding between land use and river water, but the results are inconsistent. For example, the impact of agricultural land to be weakly related to water quality [7] [10]. These results contradict most results from other researchers stating that agricultural land is strongly correlated with river water quality and primary source of river water pollution [11]. However, all the reviewed studies agreed that urban land is the primary source of the decline in water quality, and forest land has a strong influence on improving river water quality [7] [11] [12] [13].

Cirarab river basin covers three regencies/cities, namely, river upstream situated in Bogor Regency (around Rumpin District), the middle river is in Tangerang Regency and Tangerang City, and the river downstream is in Tangerang Regency. Cirarab River holds great importance for it acts as raw water for drinking water in Tangerang City. This particular function requires the river not to be polluted. However, based on the calculation of STORET index, the result shows that the water quality status of the Cirarab River is heavily polluted [14]. This tainted water condition is due to urbanization and industrialization in the Cirarab watershed. To the author's knowledge, little research has focused on the Cirarab River as a study area, whereas its function as raw water is vital for controlling water pollution and managing the river's water quality.

The purpose of this study is to analyze the impact of land use and land-use changes on the water quality of the Cirarab River by doing two things, namely: (1) analyzing the impact of land use and land use changes on the water quality of the Cirarab River in Curug District, (2) analyzing land use changes that have the most significant impact on water quality by calculating pollutant loads.

\section{The Methods}

\subsection{Study Area}

This research was conducted in Cirarab River basin Curug Tangerang Regency, covering the eastern part of the river (Curug Kulon Village, Cukang Galih Village, and Kadu Jaya Village) and western part of the river (Bunder Village, Bitung Jaya Village, Dukuh Village, and Ciakar Village) for as long as $13,546 \mathrm{~km}$ (Figure 1). The said areas were chosen because they are situated in the upstream of Cirarab River before entering Tangerang City area. 


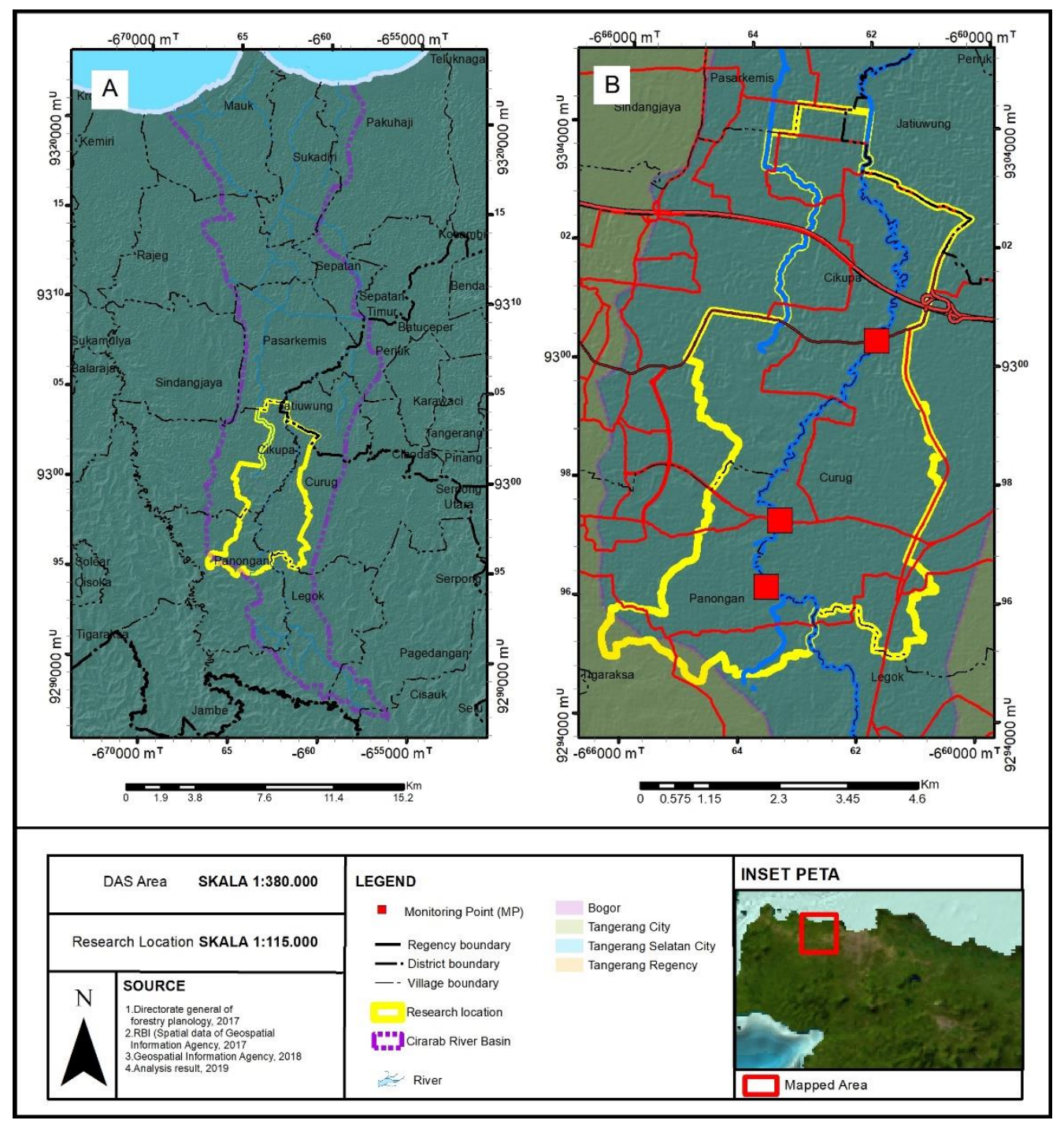

Fig. 1. (a) Cirarab River Basin (b) Research Location

Cirarab river basin is illustrated in Figure 1(a). Cirarab River is located in Java Island, passes through three regencies/cities, namely Bogor Regency, Tangerang Regency, and Tangerang City. This research was carried out in the middle part of the river, that is in Curug District segment, and in three monitoring points, which are: (A) Kadu Jaya sub segment, (B) Cukang Galih sub segment, and (C) Curug Kulon sub segment, as shown in Figure 1(b). The number of people living in the study area is 59,195 in the eastern part of the river, and 95,204 in the western part of the river with details in each village are presented in Table 1. 
Table 1. Number of People Living in Cirarab River Basin

\begin{tabular}{llllll}
\hline \multirow{2}{*}{ No } & \multirow{2}{*}{ Sub segment } & \multicolumn{2}{c}{ Western Part } & \multicolumn{2}{c}{ Eastern Part } \\
\cline { 3 - 6 } & & Village & Number of people & Village & Number of people \\
\hline \multirow{2}{*}{1} & Kadu Jaya (A) & Kadu Jaya & 23,028 & Bitung Jaya & 15,060 \\
\cline { 3 - 6 } & & & Bunder & 16,373 \\
\hline 2 & Cukang Galih (B) & Cukang Galih & 14,485 & Dukuh & 17,589 \\
\hline 3 & Curug Kulon (C) & Curug Kulon & 21,682 & Ciakar & 46,182 \\
\hline Total & & 59,195 & & 95,204 \\
\hline
\end{tabular}

Source: [15] [16] [17] (compiled)

\subsection{Study Method}

Primary data are in the form of Cirarab River water samples, photo documentation in the study area, and land use maps. Secondary data are in the form of industrial wastewater quality data obtained from the Tangerang Regency Department of Environment and Forestry/DLHK, and population data obtained from the Tangerang Regency Central Bureau of Statistics/BPS.

The 2013 and 2018 land use maps were obtained by extracting maps from Google Earth in 2013 and 2018. Land use was classified into six categories, namely (1) residential/housing, including offices, (2) industry, (3) shrubs/vacant land, (4) paddy field, (5) dryland agriculture, and (6) water bodies. Land-use change was analyzed by comparing land use maps over a period of 5 years (2013 and 2018).

Water sampling was conducted by using water sampler, by collecting sample in the middle section of the river. Water sample collecting was carried out in three monitoring points, namely in Curug Kulon Village (S: $06^{\circ} 15^{\prime} 38.718$ "E: $\left.106^{\circ} 32^{\prime} 18.78^{\prime \prime}\right)$, Cukang Galih Village (S: $06^{\circ} 15$ '05.6484 "E: $106^{\circ}$ 32' 26, 0124 "), Kadu Jaya Village (S: $06^{\circ} 13$ '24.4088" E: $106^{\circ} 33^{\prime} 17.9136$ "). Sampling collection was conducted in five collection times that represent a 24 hour cycle $(07.00 ; 11.00 ; 14.00 ; 18.00$; and $22.00 \mathrm{PM})$ in the same three monitoring points during dry season/summer, for the reason that the concentration of pollutants in the river flow was not diluted by rainwater during dry season. Physical data in the sample field were in the form of data of: (1) river water discharge, (2) $\mathrm{pH}$, and (3) temperature measured; and concentration analysis conducted in the laboratory were (4) Biochemical Oxygen Demand/BOD and (5) Chemical Oxygen Demand/COD. The results of the sample analysis were then further assessed of its quality by comparing with Government Regulation No. 82 of 2001 concerning Management of Water Quality and Water Pollution Control.

Analysis to determine which land use had the greatest impact was conducted by calculating the potential pollutant load that entered Cirarab River. The potential pollutant load measured was the pollutant load ascribed to residential and industrial activities [18] [19]. The total potential pollutant load was then compared to the maximum pollutant load allowed into the Cirarab River. The formula for calculating potential pollutant load from residential activities is presented in Formula (1). The potential pollutant load is calculated is presented in Formula (2).

Pollutant $\left(\frac{\mathrm{kg}}{\text { day }}\right)=\frac{\text { Population } \times \text { Emission factor } \times \text { equivalence ratio } \times \propto}{1_{2} 000}$ 
Emission factor:

1. $\mathrm{BOD}=40 \mathrm{gr} /$ person/day

2. $\mathrm{COD}=55 \mathrm{gr} /$ person/day

Alpha $(\alpha)$ : Load transfer coefficient $(0.3-1)$

$\alpha=1$ for location $0-100$ meter from river

$\alpha=0.85$ for location $100-500$ meter from river

Population is calculated based on comparison of the total residential area with residential that occupy areas with a distance of 100 meters, 100-500 meters, and more than 500 meters

$$
\text { Maximum Pollution Load }\left(\frac{\mathrm{kg}}{\text { day }}\right)=\text { Cmax } \times Q \times 86.4
$$

Cmax $=$ Concentration maximum on river $(\mathrm{mg} / \mathrm{L})$, base on PP 82/2001

$\mathrm{BOD}=3 \mathrm{mg} / \mathrm{L}$

$\mathrm{COD}=25 \mathrm{mg} / \mathrm{L}$

$\mathrm{Q}=$ river's debit $\left(\mathrm{m}^{3} / \mathrm{s}\right)$

$86.4=$ conversion factor to $\mathrm{kg} / \mathrm{day}$

\section{Result and Discussion}

\subsection{Land use and land-use change}

Land use was dominated by paddy field, dryland agriculture, and bush in 2013; and by residential and industry in 2018 (Figure 2). Land use pattern in Cirarab river basin segment Curug District (Table 2 and 3) consisting of land use pattern in the eastern and western part of the river. In 2018 in the eastern part of the river, land use in sub-river basin in Curug Kulon village was dominated by residential of 145.10 hectares $(46.28 \%)$, followed by paddy field of 65.98 hectares $(21.05 \%)$ and dryland agriculture of 39.54 hectares $(12.61 \%)$. Industrial area in this part was only 25.33 hectares $(8.08 \%)$, the lowest compared to the other two villages; Cukang Galih village at 54.08 hectares $(12.09 \%)$ and Kadu Jaya village at 88.00 hectares $(21.32 \%)$. In the same year, paddy field was dominant in Cukang Galih of 136.30 hectares $(30.48 \%)$, followed by residential of 104.00 hectares $(23.26 \%)$, and dryland agriculture of 76.96 hectares $(17.21 \%)$. Kadu Jaya village was dominated by shrub/vacant land of 187.80 hectares $(45.50 \%)$, followed by residential of 70.48 hectares $(17.08 \%)$. 
Table 2. Land Use Pattern in The Eastern Part of Cirarab River

\begin{tabular}{lllllll}
\hline \multirow{2}{*}{ Types of Land Use } & \multicolumn{2}{c}{ Kadu Jaya } & \multicolumn{2}{c}{ Cukanggalih } & \multicolumn{2}{c}{ Curug Kulon } \\
\cline { 2 - 7 } & 2013 & 2018 & 2013 & 2018 & 2013 & 2018 \\
\cline { 2 - 7 } & \multicolumn{5}{c}{ Surface Area (ha) } \\
\hline Residential & 44.64 & 70.48 & 40.37 & 104.00 & 59.24 & 145.10 \\
\hline Industry & 71.34 & 88.00 & 45.57 & 54.08 & 19.47 & 25.33 \\
\hline Shrub/Vacant & 187.80 & 187.80 & 75.50 & 75.50 & 35.72 & 35.72 \\
\hline Paddy field & 27.50 & 19.62 & 167.10 & 136.30 & 124.20 & 65.98 \\
\hline Dryland Agriculture & 76.00 & 41.38 & 118.30 & 76.96 & 73.04 & 39.54 \\
\hline Water Body & 5.48 & 5.48 & 0.34 & 0.34 & 1.85 & 1.85 \\
\hline Total Surface Area & 412.76 & 412.76 & 447.18 & 447.18 & 313.52 & 313.52 \\
\hline
\end{tabular}

In 2018 in the western part of the Cirarab River (Table 3), the land use of Ciakar village was dominated by residential of 251.77 hectares (42.48\%), followed by paddy field of 156.8 hectares $(26.45 \%)$, and dryland agriculture of 131.19 hectares $(22.13 \%)$. Industrial area in this village was 39.89 hectares $(6.73 \%)$, the lowest compared to the other villages. In the same year, land use in Dukuh village was dominated by dryland agriculture of 84.37 hectares $(29.82 \%)$, followed by industry of 62.85 hectares $(22.22 \%)$, and residential of 56.1 hectares $(19.90 \%)$. Bunder and Bitung Jaya were dominated by industry of 436.59 hectares (more than $50 \%$ of land use in the two villages), followed by residential of 112.43 hectares, and dryland agriculture of 107.65 hectares. The two villages were merged to adapt to the appropriate segment length, that is Kadu Jaya sub segment (A).

Table 3. Land Use Pattern in The Westerm Part of Cirarab River

\begin{tabular}{lllllll}
\hline \multirow{2}{*}{ Types of Land Use } & \multicolumn{2}{c}{ Bunder + Bitung Jaya } & \multicolumn{2}{c}{ Dukuh } & \multicolumn{2}{c}{ Ciakar } \\
\cline { 2 - 7 } & 2013 & 2018 & 2013 & 2018 & 2013 & 2018 \\
\cline { 2 - 7 } & \multicolumn{5}{c}{ Surface Area (ha) } \\
\hline Residential & 104.15 & 112.43 & 34.51 & 56.31 & 202.02 & 251.77 \\
\hline Industry & 130.47 & 436.59 & 18.68 & 62.85 & 7.51 & 39.89 \\
\hline Shrub/Vacant & 345.2 & 50.19 & 43.00 & 7.69 & 42.10 & 0.99 \\
\hline Paddy field & 68.51 & 65.16 & 57.75 & 50.19 & 187.47 & 156.80 \\
\hline Dryland agriculture & 123.69 & 107.65 & 107.63 & 84.37 & 141.54 & 131.19 \\
\hline Water Body & 1.43 & 1.43 & 21.34 & 21.50 & 12.07 & 12.07 \\
\hline Total Surface Area & 773.45 & 773.45 & 282.91 & 282.91 & 592.71 & 592.71 \\
\hline
\end{tabular}




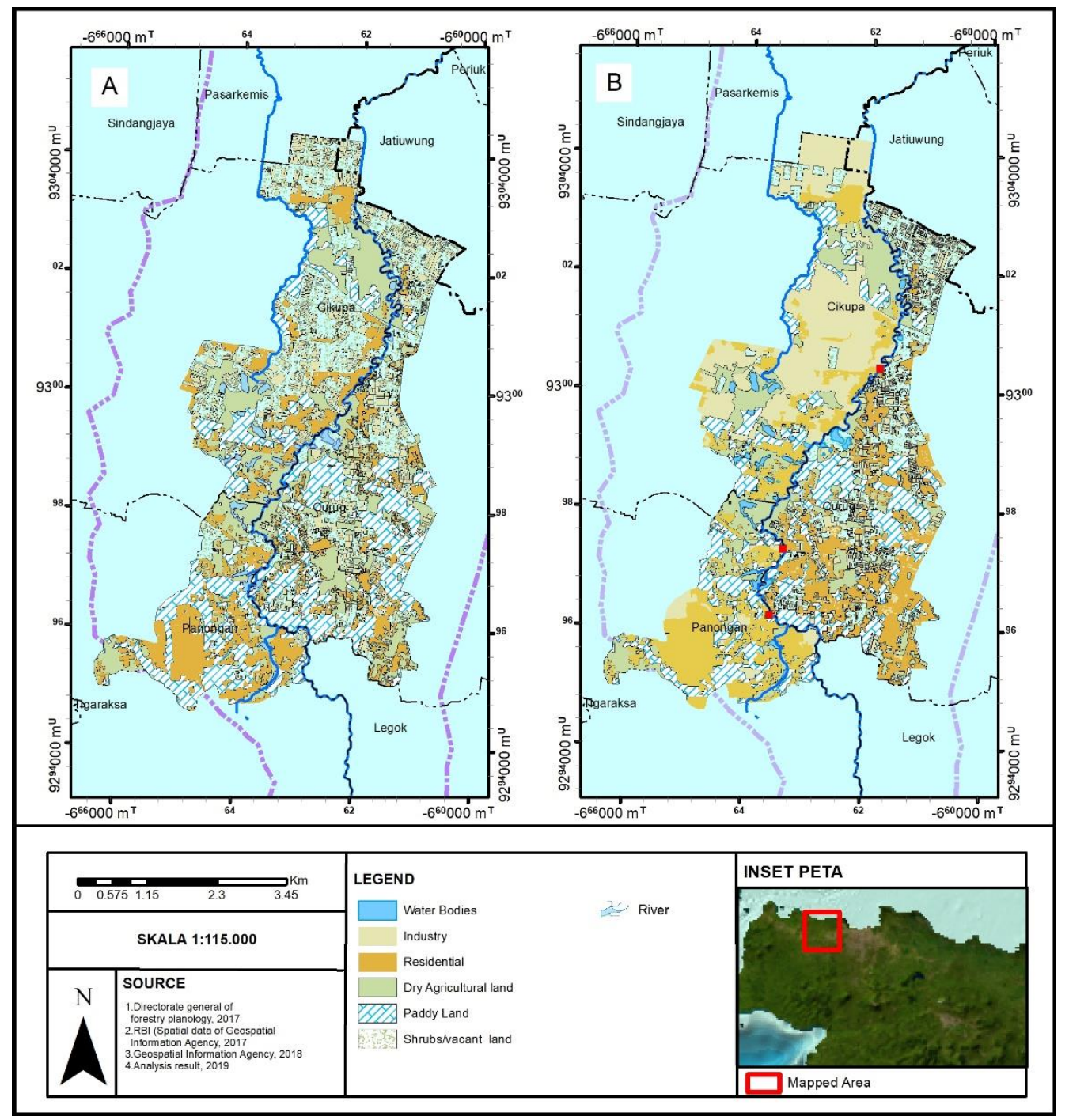

Fig. 2. Land Use Map of Cirarab River Segment Curug District, Year (a) 2013 (b) 2018

This research finds that the farther towards downstream, the higher dominance of residential and industrial land use. This result is consistent with previous findings. The farther towards river downstream in Pesanggrahan River, Indonesia, the higher land use in river basin is dominated by built land, including residential and industry [18]. Land use in Code River basin, Indonesia, was also dominated by residential area [4]. However, this result is slightly different with land use in uMngeni river basin, South Africa, was dominated by natural vegetation, cultivation, and plantation [9]. Land use in Xitiaoxi catchment of Taihu Basin, China, was dominated by forest, urban area, and agriculture [12]. Land use in the middle of 
Chao Phraya River Basin, Thailand, was dominated by paddy land and urban/built-up area [20].

Analysis on land-use change was carried out by comparing changes in surface area in each land use category within a period of 5 years (2013-2018). Land-use change in each Ciracab segment Curug District river basin are analyzed as presented in Table 4, where negative symbol (-) marks the declining land-use. In general, residential land use has increased significantly with varying surface area (ha) in the three sub river basins, along with the significant increase in industrial land use in the western part of Ciracab River. These have simultaneously reduced paddy field and dryland agriculture, and shrub/vacant land.

Table 4. Land-Use Change in Cirarab Segment Curug District River Basin

\begin{tabular}{lrrrrrr}
\hline \multirow{2}{*}{ Types of Land Use } & \multicolumn{5}{c}{ Change in Surface Area (Ha) } \\
\cline { 2 - 7 } & \multicolumn{2}{c}{ Kadu Jaya (A) } & \multicolumn{2}{c}{ Cukang Galih (B) } & \multicolumn{2}{c}{ Curug Kulon (C) } \\
\cline { 2 - 7 } & \multicolumn{1}{c}{ Eastern } & Western & Eastern & Western & Eastern & Western \\
\hline Residential & 8.31 & 25.84 & 21.79 & 63.63 & 49.75 & 85.86 \\
\hline Industry & 306.12 & 16.66 & 44.17 & 8.51 & 32.38 & 5.86 \\
\hline Shrub/Vacant & -295.01 & 0.00 & -35.31 & 0.00 & -41.11 & 0.00 \\
\hline Paddy field & -3.35 & -7.88 & -7.56 & -30.80 & -30.67 & -58.22 \\
\hline Dryland agriculture & -16.04 & -34.62 & -23.26 & -41.34 & -10.35 & -33.50 \\
\hline Water Body & 0.00 & 0.00 & 0.16 & 0.00 & 0.00 & 0.00 \\
\hline
\end{tabular}

In Tangerang Regency, the largest increase in residential development occured in Curug Kulon (C) sub segment of 85.86 hectares in its eastern part and 49.75 hectares in its western part; followed by Cukang Galih (B) sub segment of 63.63 hectares in its eastern part and 21.79 hectares in its western part, and in Kadu Jaya (A) sub segment of 8.31 hectares in its eastern part and 25.84 hectares in its western part. This increase is a result of population growth. In addition, Tangerang Regency has experienced urbanization as an impact of growing industry. From urban development perspective, the rapid growth of elite residential (public housing) is one of the main factors in land-use change [4]. Land conversion from paddy fields and dryland agriculture and shrubs/vacant land to industrial area, did occur in the research area. The largest land conversion took place in Kadu Jaya sub segment (A) of 306.12 hectares from shrubs/vacant land, paddy fields, and dryland agriculture. These findings concur that land use change occurred as a result of urbanization and industrialization. Urbanization and industrial expansion are potential to changing land use [21]. Population growth followed by industrial increase leads to the declining water quality in Asia [22].

\subsection{River water quality of Cirarab River segment Curug District}

The assessment of river water quality based on four physical and chemical parameters, namely (1) temperature, (2) pH, (3) BOD, and (4) COD. The measurement results compared with river water quality standards set by the Government of the Republic of Indonesia through the Government Regulation of the Republic of Indonesia No. 82 the year 2001 about Management of Water Quality and Control of Water Pollution. 
Table 5. Cirarab River Segment Curug District Water Quality, 2018

\begin{tabular}{|c|c|c|c|c|c|c|}
\hline \multirow[b]{2}{*}{ Monitoring Points (MP) } & \multirow[b]{2}{*}{$\begin{array}{l}\text { Collection } \\
\text { Time }\end{array}$} & \multicolumn{5}{|c|}{ Parameter } \\
\hline & & $\begin{array}{c}\text { Water } \\
\text { Discharge } \\
\left(\mathrm{m}^{3} / \mathrm{s}\right)\end{array}$ & $\begin{array}{c}\text { Temperature } \\
\left({ }^{\circ} \mathrm{C}\right)\end{array}$ & $\begin{array}{c}\text { BOD } \\
(\mathrm{mg} / \mathrm{L})\end{array}$ & $\begin{array}{l}\text { COD } \\
(\mathrm{mg} / \mathrm{L})\end{array}$ & $\mathrm{pH}$ \\
\hline MP 1 (Curug Kulon) & 07.00 & 4.9 & 28.3 & 15 & 70 & 7.18 \\
\hline $\mathrm{S}: 06^{\circ} 15^{\prime} 38,718^{\prime \prime}$ & 11.00 & 5.4 & 29 & 17 & 72 & 7.05 \\
\hline \multirow[t]{3}{*}{$\mathrm{E}: 106^{\circ} 32^{\prime} 18,78^{\prime \prime}$} & 15.00 & 3.1 & 28.8 & 24 & 73 & 7.25 \\
\hline & 18.00 & 6 & 28.3 & 21 & 61 & 7.09 \\
\hline & 22.00 & 5.8 & 27.8 & 19 & 61 & 7.05 \\
\hline MP 2 (Cukang Galih) & 07.00 & 1.1 & 27.9 & 6 & 36 & 7.27 \\
\hline S : 06॰ 15'05,6484" & 11.00 & 1.6 & 28.8 & 13 & 43 & 8.08 \\
\hline $\mathrm{E}: 106^{\circ} 32^{\prime}$ & 15.00 & 1.6 & 28.8 & 3 & 15 & 7.4 \\
\hline \multirow[t]{2}{*}{$26,0124 "$} & 18.00 & 1.2 & 27.9 & 18 & 60 & 6.89 \\
\hline & 22.00 & 1.5 & 27.6 & 13 & 39 & 6.73 \\
\hline MP 3 (Kadu Jaya) & 07.00 & 2 & 29.4 & 6 & 35 & 7 \\
\hline S : 06॰ 13' 28,4088" & 11.00 & 2.6 & 30.1 & 7 & 42 & 7.24 \\
\hline E : $106^{\circ} 33^{\prime}$ & 15.00 & 2.6 & 29.3 & 21 & 68 & 7.58 \\
\hline \multirow[t]{2}{*}{$17,9136 "$} & 18.00 & 1.9 & 28.7 & 57 & 124 & 6.92 \\
\hline & 22.00 & 1.8 & 28 & 8 & 48 & 6.77 \\
\hline Water quality standard & & - & Dev.3 & 3 & 25 & $6-9$ \\
\hline
\end{tabular}

Curug Kulon sub segment had the most abundant water discharge with an average of 5.4 $\mathrm{m}^{3} / \mathrm{s}$, followed by MP 3 (Kadu Jaya sub segment) of $2.18 \mathrm{~m}^{3} / \mathrm{s}$ and MP 2 (Cukang Galih sub segment) of $1.4 \mathrm{~m}^{3} / \mathrm{s}$ (Table 5). The amount of river water discharge is directly proportional to the cross-sectional area of the river, and the cross-sectional area of the river is directly proportional to the depth and width of the river. So, put the more extensive the river, the larger the water discharge. Based on observations in MP 3 and MP 2, the river width is per water discharge; namely, MP 3 has a large river width and large water discharge, and MP 2 has a narrow river width and small water discharge. However, MP 2 has a large width but small water discharge. This condition caused by the presence of garbage along the water body that causes river narrowing and siltation.

Results from $\mathrm{pH}$ and temperature (Table 5) testing in all monitoring points met the required environmental quality standards, even at relatively high levels. The water quality standard used in this research was deviation three temperature, which means air temperature is $\pm 3^{\circ} \mathrm{C}$. Tangerang Regency had air temperature ranging from $24-30^{\circ} \mathrm{C}$. MP 3 had the highest air temperature with a range of $28-30.1^{\circ} \mathrm{C}$, followed by MP 1 with a range of $27.8-29{ }^{\circ} \mathrm{C}$, and MP 2 with a range of $27.6-28.8^{\circ} \mathrm{C}$. The highest $\mathrm{pH}$ concentration was in MP 2 (from 8.898.08), this high concentration still met the required water quality standard (6-9); MP 3 had a range of 6.77-7.58 and MP 1 had a range of 7.05-7.25. Table 5 shows high temperature in all 
MPs. One of the causes of the relatively high air temperature was because there was no forest land use in the research are, whereas forest is crucial to decrease physical ( $\mathrm{pH}$ and air temperature) and chemical parameters concentration [7] [11].

Concentration of BOD and COD (Table 5) in each MP failed to meet the required water quality standard $(3 \mathrm{mg} / \mathrm{L}$ and $25 \mathrm{mg} / \mathrm{L})$. The concentration values vary between $\mathrm{COD}$ and BOD, where COD value being was higher that BOD. BOD variation was caused by the concentration of biodegradable organic waste, e.g. protein, sugar, and carbohydrates, and Nitrogen in free form (e.g. NH4 $4^{-}$, which is immeasurable in COD. Therefore, COD has higher values than BOD because COD laboratory analysis involves more stable compounds in biological reactions, which may be oxidized during analysis [23].

The highest concentration of BOD and COD was in MP 3 with a range of 6-57 mg/L and 35-124 mg/L, followed by MP 1 with a range of 15-24 mg/L and 61-73 mg/L, and MP 2 with a range of 3-18 mg/L and 15-60 mg/L. Fascinatingly, when the sample collected in MP 2 at 15.00 , the concentration of BOD and COD met the required water quality standard. Further, the lowest concentration of BOD and COD was found in MP 2 because paddy field, dryland agriculture, and shrub/vacant land dominated land use in MP 2 river basin, while the residential area was scarce. Agricultural land use contributes little to river pollution [10] [7]. MP 3 had the highest concentration of BOD and COD. MP 3 was the most extended area in Cirarab river basin. Although in the eastern part of the river was dominated by shrub/vacant land use, but it was not located right in the river basin. In the western part of the river was dominated by the industrial area that sat on more than $50 \%$ of total surface area in the particular area. Field observation affirmed that industry and residential dominated the river basin. People in the residential area throw their domestic waste directly in the river.

Moreover, this condition worsened by only very few industries that have waste treatment installations. River water quality is mainly affected by incompletely treated waste entering river flow [24] [7] [20]. Meanwhile, residential contributed the most pollutant in MP 1 . Residential is strongly correlated to river water quality [25]. Urbanization thus expands waterresistant areas which cause waste to flow faster into the river with an enormous amount of runoff, which will increase the pollutant concentration in the river [7].

\subsection{Potential Pollutant Load}

Land use in 2018 was dominated by residential, thus it is necessary to understand pollutant load from residential activities. Residential activities put pressure on Cirarab river water quality due to domestic wastewater disposal. Number of people living in each sub river basin from eastern and western part, was calculated based on method approach of percentage residential area with a distance of $<100 \mathrm{~m}, 100-500 \mathrm{~m}$, and $>500 \mathrm{~m}$. 
Table 6. Population in Each Cirarab Sub Segment

\begin{tabular}{|c|c|c|c|c|c|c|c|}
\hline No & $\begin{array}{l}\text { Sub } \\
\text { segment }\end{array}$ & Part & $\begin{array}{l}\text { Total } \\
\text { residential area } \\
\text { (ha) }\end{array}$ & $\begin{array}{l}\text { Distance to } \\
\text { river }(\mathrm{m})\end{array}$ & Residen & a (ha) & $\begin{array}{l}\text { Number } \\
\text { of people }\end{array}$ \\
\hline \multirow{6}{*}{1} & \multirow{6}{*}{$\begin{array}{l}\text { Curug } \\
\text { Kulon }\end{array}$} & \multirow{3}{*}{ eastern } & \multirow{3}{*}{145.10} & $<100$ & 3.07 & $2 \%$ & 459 \\
\hline & & & & $100-500$ & 23.7 & $16 \%$ & 3,541 \\
\hline & & & & $>500$ & 118.33 & $82 \%$ & 17,682 \\
\hline & & \multirow{3}{*}{ western } & \multirow{3}{*}{251.77} & $<100$ & 24.39 & $10 \%$ & 4,474 \\
\hline & & & & $100-500$ & 11.1 & $4 \%$ & 2,036 \\
\hline & & & & $>500$ & 216.28 & $86 \%$ & 39,672 \\
\hline \multirow{6}{*}{2} & \multirow{6}{*}{$\begin{array}{l}\text { Cukang } \\
\text { Galih }\end{array}$} & \multirow{3}{*}{ eastern } & \multirow{3}{*}{104} & $<100$ & 3.22 & $3 \%$ & 448 \\
\hline & & & & $100-500$ & 31.61 & $30 \%$ & 4,403 \\
\hline & & & & $>500$ & 69.17 & $67 \%$ & 9,634 \\
\hline & & \multirow{3}{*}{ western } & \multirow{3}{*}{56.31} & $<100$ & 9.54 & $17 \%$ & 2,980 \\
\hline & & & & $100-500$ & 24.39 & $43 \%$ & 7,618 \\
\hline & & & & $>500$ & 22.38 & $40 \%$ & 6,991 \\
\hline \multirow{6}{*}{3} & \multirow{6}{*}{$\begin{array}{l}\text { Kadu } \\
\text { Jaya }\end{array}$} & \multirow{3}{*}{ eastern } & \multirow{3}{*}{70.48} & $<100$ & 4.55 & $6 \%$ & 1,487 \\
\hline & & & & $100-500$ & 31.27 & $44 \%$ & 10,217 \\
\hline & & & & $>500$ & 34.66 & $49 \%$ & 11,324 \\
\hline & & \multirow{3}{*}{ western } & \multirow{3}{*}{112.43} & $<100$ & 18.48 & $16 \%$ & 5,167 \\
\hline & & & & $100-500$ & 54.35 & $48 \%$ & 15,195 \\
\hline & & & & $>500$ & 39.60 & $35 \%$ & 11,071 \\
\hline
\end{tabular}

Population of people living 100 meters from river is mostly located in Kadu Jaya sub segment as many as 6,653, followed by Curug Kulon sub segment as many as 4,933, and Cukang Galih sub segment many as 3,428 (Table 6). Population living within 100 meters distance from the river put higher pollution pressure compared to population living more than 100 meters. Population living within 100-500 meters also put great pressure towards water quality. These two types of population (living < $100 \mathrm{~m}$ and 100-500 m) mostly lived in Cukang Galih and Kadu Jaya sub segment, while population in Curug Kulon sub segment was mostly lived more than 500 meters from the river. 
Table 7. Pollutant Load in Each Sub Segment

\begin{tabular}{|c|c|c|c|c|c|c|c|c|c|}
\hline \multirow{2}{*}{ No } & \multirow{2}{*}{ Sub segment } & \multirow{2}{*}{$\begin{array}{l}\text { Number } \\
\text { of people }\end{array}$} & \multirow{2}{*}{$\begin{array}{l}\text { Distance } \\
\text { to river } \\
(\mathrm{m})\end{array}$} & \multirow{2}{*}{$\begin{array}{l}\text { alpha } \\
(\alpha)\end{array}$} & \multicolumn{2}{|c|}{$\begin{array}{c}\text { Emission } \\
\text { factor }\end{array}$} & \multirow{2}{*}{$\begin{array}{l}\text { equivalen } \\
\text { ratio }\end{array}$} & \multicolumn{2}{|c|}{$\begin{array}{l}\text { Pollutant Load } \\
\text { (kg/day) }\end{array}$} \\
\hline & & & & & BOD & COD & & BOD & COD \\
\hline \multirow{3}{*}{1} & \multirow{3}{*}{ Curug Kulon } & 4,933 & $<100$ & 1 & \multirow{9}{*}{40} & \multirow{9}{*}{55} & \multirow{9}{*}{0.8125} & 160.31 & 220.42 \\
\hline & & 5,578 & $100-500$ & 0.85 & & & & 154.08 & 211.86 \\
\hline & & 57,354 & $>500$ & 0.3 & & & & 559.20 & 768.90 \\
\hline \multirow{3}{*}{2} & \multirow{3}{*}{$\begin{array}{l}\text { Cukang } \\
\text { Galih }\end{array}$} & 3,428 & $<100$ & 1 & & & & 111.42 & 153.21 \\
\hline & & 12,021 & $100-500$ & 0.85 & & & & 332.08 & 456.61 \\
\hline & & 16,625 & $>500$ & 0.3 & & & & 162.09 & 222.87 \\
\hline \multirow{3}{*}{3} & \multirow{3}{*}{ Kadu Jaya } & 6,653 & $<100$ & 1 & & & & 216.23 & 297.32 \\
\hline & & 25,412 & $100-500$ & 0.85 & & & & 702.01 & 965.26 \\
\hline & & 22,396 & $>500$ & 0.3 & & & & 218.36 & 300.24 \\
\hline Total & & 154,399 & & & & & & $2,615.78$ & $3,596.69$ \\
\hline
\end{tabular}

Total potential pollutant load entering Cirarab river in 2018 based on calculation was 2,615.78 kgBOD/day and 3,596.69 kgCOD/day (Table 7). The highest BOD and COD pollutant load occurred due to residential activities in Kadu Jaya and Cukang Galih sub segment from residential located within 100 meters and 100-500 meters from the river. In general, 200 meters riparian zone landscape had a slightly greater effect on the water than subcatchments [12]. Pollutant load from residential activities is directly proportional to the number of people living in the area, in addition to being affected by distance to the river and urban equivalent ratio. Since Tangerang Regency is a suburb, its equivalent ratio is 0.8125 . Pollutant load from human activities closer to the river was higher than human activities farther from the river. Based on the calculation, Kadu Jaya sub segment produced the most waste compared to the other. This result is consistent with water quality in each sub segment.
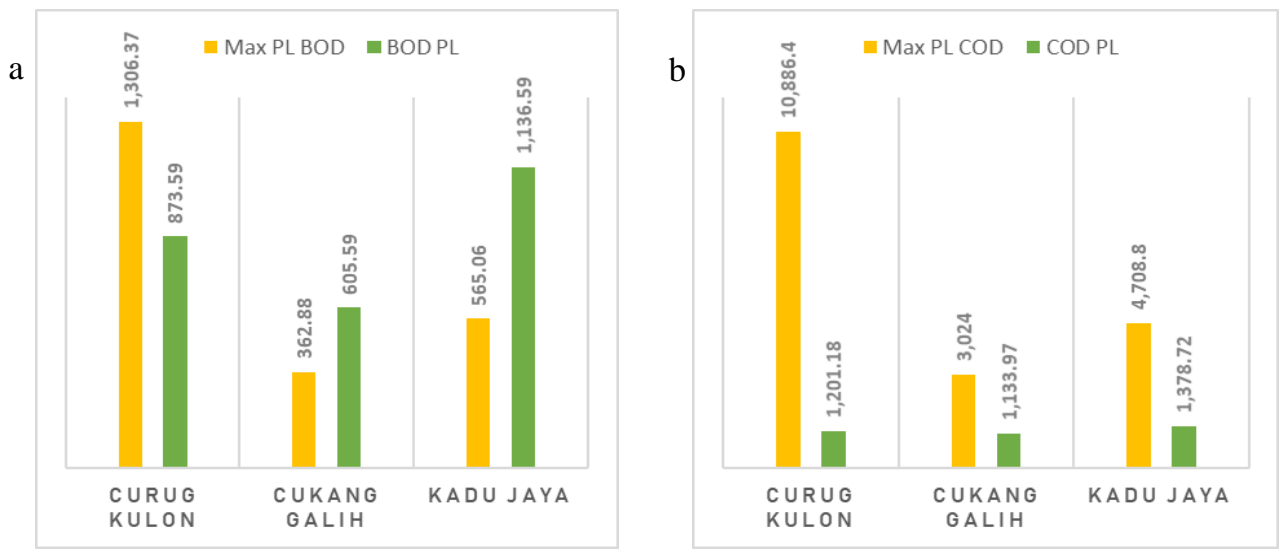

Fig. 3. Comparison between maximum pollutant load exsisting parameter (a) BOD (b) COD 
The result of comparison between the maximum pollutant load existing parameter (Figure 3), showed that Kadu Jaya sub segment had the highest pollutant waste of 1,136.59 $\mathrm{kgBOD} /$ day, followed by Curug Kulon sub segment of $873.59 \mathrm{kgBOD} /$ day, and Cukang Galih sub segment of $605.59 \mathrm{kgBOD} /$ day. For COD pollutant load, Kadu Jaya sub segment produced the highest pollutant waste of $1,378.72 \mathrm{kgCOD} /$ day, followed by Curug Kulon sub segment of 1,201.18 kgCOD/day, and Cukang Galih sub segment of 1,133.97 kgCOD/day. The three sub segment did not exceed the maximum pollutant load for COD parameters. However, for BOD parameters, the pollutant load entering the river far exceeded the maximum pollutant load in Kadu Jaya and Cukang Galih sub segment. High pollutant load increases BOD and COD values. High BOD and COD values, increases the Oxygen needed by microorganism to break down organic matter, which results in a decrease in dissolved oxygen in the river. Low dissolved oxygen content indicates that the river has been contaminated [19].

\section{Conclusion}

The results reveals that residential area acts as the primary contributor to water river pollution, due to the rough treatment of domestic waste disposal. The largest residential area is in the Curug Kulon sub segment of 396.87 hectares, followed by Kadu Jaya sub segment of 182.91 hectares, and Cukang Galih sub segment of 160.31 hectares. However, a larger residential area does not guarantee the highest pollution pressure to the river since the distance of the residential area from the river also contributes to it. Land-use change occurs to meet human needs. Urbanization and industrialization in the research area caused land conversion from non-residential area to the residential area. The most significant land-use change is from paddy field and dryland agricultural area to the residential area. From calculating the amount of pollutant load from residential activities that enter the river, this research concludes that the most significant pollutant load is consistent with the worst water quality. Kadu Jaya sub segment with pollutant load of $1,136.59 \mathrm{kgBOD} /$ day and 1,378.72 $\mathrm{kgCOD} /$ day, and produced high BOD and COD value of $57 \mathrm{mg} / \mathrm{L}$ and $124 \mathrm{mg} / \mathrm{L}$. This high BOD and COD value far exceeded the allowed water quality standard. Despite its complexity, land use in the river basin has become a proper indicator to predict water quality. Understanding the impact of land use in the river basin is useful to formulate the correct strategy in river management and land use treatment in the river basin.

Acknowledgement. This Research is funded by the Grant of Indexed International Publication for Final Project of Magister Students from Directorate of Research and Community Service, Universitas Indonesia number NKB-1021/UN2/R3.1/HKP.05.00/2019.

\section{References}

[1] UNWater.: Water. [online]. Retrieved from http://www.un.org/en/sections/issuesdepth/water/ (2018)

[2] UNWater.: Policy Brief: Water Quality. [online]. Retrieved from www.un.org (2011) 
[3] Suriawiria, U.: Air dalam Kehidupan and Lingkungan yang Sehat. Bandung: PT. Alumni (2005) [Indonesian]

[4] Muryanto, Suntoro, Gunawan, T., \& Setyono, P.: Land use, climate parameters and water quality changes at suroundings of Code River, Indonesia. IOP Conf. Series: Earth and Environmental Science. Vol. 129, pp. 1-7 (2018)

[5] Kang, J.H., Lee, S.W., Cho, K.H., Ki, S.J., Cha, S.M., \& Kim, J.H.: Linking land-use type and stream water quality using spatial data of fecal indicator bacteria and heavy metals in the Yeongsan River basin. Water Res. Vol. 44, pp. 4143-4157 (2010)

[6] Izzati, U., \& Hasibuan, H.S.: Riparian bird diversity in Cisadane River, South Tangerang City, Indonesia. Biodiversitas. Vol. 20(2), pp. 595-603 (2019)

[7] Ding, J., Jiang, Y., Fu, L., Liu, Q., Peng, Q., \& Kang, M.: Impact of Land Use on Surface Water in a Subtropical River Basin: A Case Study of the Dongjiang River Basin, Southeastern China. Water. Vol. 7, pp. 4427-4445 (2015)

[8] Li, Y., Li, Y., Qureshi, S., Kappas, M., \& Hubacek, K.: On The Relationship between Landscape Ecological Patterns and Water Quality Across Gradient Zones of Rapids Urbanization in Coastal China. Ecol. Model. Vol. 7456, pp. 1-9 (2015)

[9] Namugize, J., Jewitt, G., \& Graham, M.: Effects of land use and land cover changes on water quality in the uMngeni river catchment, South Africa. Physics and Chemistry of the Earth, Parts A/B/C. Vol. 105, pp. 247-264 (2018)

[10] Azyana, Y., Norulaini, N., \& Jannah, N.: Land use and catchment size/scale on the water quality deterioration of Kinta River, Perak, Malaysia. Malaysia Journal of Science. Vol. 31(2), pp. 121-131 (2012)

[11] Camara, M., Jamil, N.R., \& Fikri bin Abdullah, A.F.: Impact of land uses on water quality in Malaysia: a review. Ecological Processes. Vol. 8(10), pp. 1-10 (2019)

[12] Lv, H., Xu, Y., Han, L., \& Zhou, F.: Scale-dependence effects of landscape on seasonal water quality in Xitiaoxi catchment of Taihu Basin, China. Water Science \& Technology. Vol. 71(1), pp. 59-66 (2015)

[13] Kandlër, M., Blechinger, K., Seidler, C., et al.: Impact of land use on water quality in the upper Nisa catchment in the Czech Republic and in Germany. Science of The Total Environment. Vol. 586, pp. 1316-1325 (2017)

[14] Agrarini, A.T.: Kualitas Perairan Pesisir Cituis Kabupaten Tangerang, Banten. Skripsi. Institut Pertanian Bogor (2014) [Indonesian]

[15] BPS Kab. Tangerang.: Kecamatan Panongan dalam angka (2017) [Indonesian]

[16] BPS Kab. Tangerang.: Kecamatan Curug dalam angka (2018a) [Indonesian]

[17] BPS Kab. Tangerang.: Kecamatan Cikupa dalam angka (2018b) [Indonesian]

[18] Effendi, H., Muslimah, S., \& Permatasari, P.A.: Relationship between land use and water quality in Pesanggrahan River. IOP Conf. Series: Earth and Environmental Science. Vol. 149, pp. 1-10 (2018)

[19] Hikmat, R.R., \& Juwana, I.: Pollution load of Cisangkan River: The Domestic sector. IOP Conf. Series: Earth and Environmental Science. Vol. 277, pp. 1-8 (2019)

[20] Singkran, N., Ananntawong, P., Intharawichian, N., \& Kunta, K.: The Chao Phraya River Basin: water quality and anthropogenic influences. Water Science \& Technology: Water Supply. pp. 1-8 (2018)

[21] Teixeira, Z., Teixeira, H., \& Marques, J.C.: Systematic processes of land use/land cover change to identify relevant driving forces: Implication on water quality. Science of the Total Environment. Vol. 470-471, pp. 1320-1335 (2014) 
[22] Giri, S., \& Qiu, Z.: Understanding the relationship of land uses and water quality in Twenty First Century: A review. Journal of Environmental Management. Vol. 173, pp. 41-48 (2016)

[23] Setiawan, A.D., Widyastuti, M., \& Hadi, M.P.: Water quality modeling for pollutant carrying capacity assessment using Qual2Kw in Bedog River. Indonesian Journal of Geography. Vol. 50(1), pp. 49-56 (2018)

[24] Jiang, Y., Ding, Z., Peng, Q., Liao, J., \& Lv, L.: Spatial Distribution and Corresponding Factors of Heavy Metals Concentrations in the Dongjiang River Basin, Southeast China. Res. J. Env. Earth Sci. Vol. 4, pp. 448-459 (2012)

[25] Bu, H., Meng, W., Zhang, Y., \& Wan, J.: Relationships between land use patterns and water quality in the Taizi River basin, China. Ecological Indicators. Vol. 41, pp. 187-197 (2014) 